Original Research

\title{
Modern and Classic Wound Dressing Comparison in Wound Healing, Comfort and Cost
}

\section{Ferdiansyah Mahyudin, Mouli Edward, M. Hardian Basuki, Yunus Basrewan, and Ansari Rahman}

Orthopaedic and Traumatology Department, Faculty of Medicine, Universitas Airlangga - RSUD Dr. Soetomo, Surabaya, East Java, Indonesia

\begin{abstract}
Introduction: Wound care has also developed rapidly after the dissemination of the concept of TIME (Tissue, Infection, Moisture, and Wound Edge) in modern dressing (MD). The aim of this study was to compare modern dressings (MDs) and classic dressings (CDs) in terms of patient comfort, cost effectiveness and wound healing.

Methods: A prospective study design with total of 25 participants. The sampling technique used was consecutive sampling. Patient comfort was assessed through the frequency of wound care and pain scale using the Visual Analogue Scale (VAS). Cost-effectiveness was assessed using direct and indirect costs. Wound healing was assessed using the Bates-Jensen Wound Assessment Tool (BWAT) score. The data was analyzed using the independent $t$ and Mann-Whitney tests.
\end{abstract}

Results: In terms of comfort, the mean for the number of times that wound care was performed and the pain scale in the participants using MD was $(3.07 \pm 0.88$ times and VAS $4.59 \pm 0.72$, respectively), which is less compared to using CD (4.60 \pm 1.84 times each and VAS $5.43 \pm 0.75)$. Referring to the indirect and direct costs, MD (13.67 \pm 6.09 and $527.63 \pm 84.47$, respectively) has the same cost-effectiveness as $C D$ (14.00 \pm 7.64 and $482.68 \pm 98.08$, respectively). In terms of healing, the mean of the BWAT score in MD (31.26 \pm 1.69$)$ was better compared to CD (33.07 \pm 1.65$)$.

Conclusion: The application of MD has the same cost-effectiveness as CD with a more satisfactory outcome for the wounds in terms of comfort and healing.

\section{ARTICLE HISTORY}

Received: Dec 10, 2019

Accepted: January 28, 2020

\section{KEYWORDS}

classic dressing; cost effectiveness; modern dressing; patient comfort; wound healing

\section{CONTACT}

Ferdiansyah Mahyudin $\square$ ferdiansyah@fk.unair.ac.id $\doteq$ Orthopaedic and Traumatology Department, Faculty of Medicine, Universitas Airlangga RSUD Dr. Soetomo, Surabaya, East Java, Indonesia

Cite this as: Mahyudin, F., Edward, M., Basuki, M. H., Basrewan, Y., \& Rahman, A. (2020). Modern and Classic Wound Dressing Comparison in Wound Healing, Comfort and Cost. Jurnal Ners, 15(1), 31-36. doi:http://dx.doi.org/10.20473/in.v14i2. 16597

\section{INTRODUCTION}

A wound is a disorder of the normal condition of the skin in the form of damage to its continuity due to a pathological process, be it internal or external. Wounds often occur in daily life and they can lead to serious complications if not treated adequately (Gonzalez, Andrade, Costa, \& Medrado, 2016).

The incidence of wounds is increasing annually. More than 1.2 million people have died globally due to traffic accidents and between 20-50 million people have suffered non-fatal injuries, including wounds. Most injuries, both acute and chronic in the global population, are caused by trauma (48.00\%), foot ulcers $(28.00 \%)$ and pressure sores $(21.00 \%)$. Acute wounds occur with a rapid onset and the healing process can be estimated. For example, injuries due to trauma or surgery. The healing process for chronic wounds cannot be predicted, for example, as in pressure ulcers, injuries due to malignancy and others (Gurtner, 2007). In developing countries, 1-2\% of the population is predicted to have suffered from a chronic injury during their lifetime (Hurley, Knepper, \& Price, 2013).

In Indonesia, the incidence of injuries is quite high along with the increasing incidence of traffic accidents in recent decades. In Surabaya, particularly at the Dr. Soetomo Regional General Hospital in Surabaya, 147 orthopedic patients with injuries were treated in the Acute Surgical Treatment Room 
between January 2016 and March 2017. There was a male to female ratio of four to one; $90 \%$ of them were injuries due to trauma.

Both acute and chronic wounds require good wound care and management. Wound management is an act of wound care that includes all elements including comorbid control and complications that can result from an injury. The series of activities include cleaning the wound and changing the dressing. The conventional wound care that is often done using tulle and gauze requires a long healing time, especially for chronic wounds with certain complications. Long days of care and visits conducted by the medical personnel that need to be more frequent will have an impact on the cost of care. In addition, in terms of comfort, patients treated using conventional bandages often complain of pain when dressing because the wound tends to adhere with the dressing (Morrison, Moffatt, \& Franks, 2007).

In the last two decades, wound care has experienced rapid developments. Developments in the field of wound care began knowledge of the TIME concept (Tissue, Infection, Moisture, and Wound Edge) was been applied to the MD that is widely circulating today. MDs are a product of high-tech wound dressing. This type of dressing is able to control the humidity around the wound. A humid atmosphere will help to provide the atmosphere needed for there to be a local defense made by macrophages, accelerating angiogenesis and thus accelerating the wound healing process. In addition, it is expected that the use of MD can further increase the cost effectiveness and comfort of the patients (Daunton, Kothari, Smith, \& Steele, 2012).

The application of wound care methods through the MD route in Indonesia is still relatively small. This is because the majority of health care facilities tend to use CD. The aim of this study was to compare modern dressings (MDs) and classic dressings (CDs) in terms of patient comfort, cost effectiveness and wound healing.

\section{MATERIALS AND METHODS}

This was a clinical observational study conducted using a prospective design approach in order to compare the outcome of wound care between MD and CD. The research subjects were orthopedic and traumatology patients with wounds treated in the surgical ward of Dr. Soetomo Regional General Hospital in Surabaya between March 2018 and February 2019. The inclusion criteria consisted of acute wounds caused by trauma where the raw surface of the wounds was $50-500 \mathrm{~cm} 2$ and where the depth of the wound ranged from partial to full thickness with skin loss down to muscle level. The exclusion criteria in this study included wounds with a raw surfaces of less than $50 \mathrm{~cm} 2$ or more than 500 $\mathrm{cm} 2$, wounds that are without an exposure of bone, tendon, nerve, vascular and cartilage and wounds in patients with multiple traumas or with comorbidities like anemia, hypoalbuminemia or systemic diseases such as diabetes mellitus or malignancy.

The dependent variable in this study is the type of dressing (MD and CD) while the independent variables are (1) patient comfort assessed by how often wound care was performed and the pain scale each time that wound care was performed, (2) cost effectiveness as seen from the direct and indirect costs and (3) wound healing. Wound care was carried out by the orthopedic resident based on the standard operational procedures for wound care in the hospital of Surabaya Province. First, hand scrubbing was conducted. An explanation of the procedure of wound care was given to the patient, followed by patient identification. The use of gloves was emphasized. The wound dressing was removed with tweezers and disposed of. The wound was cleaned with gauze and $\mathrm{NaCl} 0.9 \%$ from the inside out. The condition of the wound was noted and documented. The wound was closed with a primary dressing, followed by a secondary dressing. The dirty gauze was disposed of and the tweezers were cleaned in a $0.5 \%$ chlorine solution.

MD is a type of wound dressing that consists of CutimedSiltec $₫$ and CutimedSorbact $\AA$. This is a standard modern dressing in the hospital. CD is a type of wound dressing that consists of gauze and tulle. Patient comfort was assessed according to the frequency of wound care being performed until the wound was ready for definitive therapy with a soft tissue coverage procedure. The pain scale each time wound care was performed was assessed by VAS. VAS is a pain rating scale with points along the length of a $10-\mathrm{cm}$ line that represents a continuum between "no pain" at the left end $(0 \mathrm{~cm})$ of the scale and the "worst pain" at the right end of the scale $(10 \mathrm{~cm})$ (Bechert \& Abraham, 2009; Delgado et al., 2018). Cost effectiveness was assessed through the direct costs referring to the costs directly related to wound care including wound dressing materials, the use of pain medication during wound care, the use of antibiotic drugs due to complications from infected wounds and the hospital costs. Cost effectiveness was also assessed using indirect costs, referring to costs that are not directly related to the treatment process, including productivity problems, as well as the costs incurred by the patient's carer during their stay in hospital. This is directly proportional to their length of stay (LOS) (Al-Gharibi, Sharstha, \& Al-Faras, 2018). Wound healing refers to where the wound condition was assessed using the BWAT score (see Table 3) every time that wound care was performed (BatesJensen, McCreath, Harputlu, \& Patlan, 2019).

All of the data was tested for normality distribution using the Kolmogorov Smirnov test. Variant homogeneity was determined using the Levene test. The data that was normally distributed with homogeneous variants was compared using an independent T-test while the data that was not normally distributed with non-homogeneous variants was compared using the Mann-Whitney test. 
This research has been approved by the Commission of Health Research Ethics Faculty of Dr. Soetomo General Hospital Surabaya no. 52/Panke.KKE/II/2018 on 13th February 2018.

\section{RESULTS}

The results of this study have been presented in tables and diagrams. The patients with wounds treated using MD totaled 13 men and 2 women. The patients with wounds treated using CD amounted to 6 men and 4 women. Patients with wounds treated using MD consisted of 6 people aged less than 30 years old, 5 people aged 30 to 50 years old and 4 people aged over 50 years old. Patients with wounds treated using CD consisted of 4 people aged less than 30 years old, 4 people aged 30 to 50 years old and 2 people aged more than 50 years old. Seven patients treated using MD suffered from upper extremity wounds and 8 patients suffered from lower extremity wounds. The patients with wounds treated using CD consisted of 1 person suffering from a wound in the upper extremities and 9 people suffering from wounds in the lower extremities. The complete data of these patients has been described in Table 1 .

Based on Table 2, the area of the wounds in patients treated with MD was $233.13 \pm 91.97$, the same as the area of the wounds treated with CD:170.60 $\pm 117.01(p>0.05)$. The mean number of times that wound care performed in patients using MD (3.07 \pm 0.88$)$ was less than the wound care frequency for patients using CD $(4.60 \pm 1.84)$. There was a significant difference $(\mathrm{p}<0.05)$. The initial VAS in patients treated with MD was $7.27 \pm 0.96$, which is the same as the initial VAS in patients treated with CD of $7.40 \pm 0.84(\mathrm{p}>0.05)$. The last VAS in patients using MD (2.60 \pm 0.63$)$ was less than the last VAS in patients using $C D(3.90 \pm 0.74)$; there were significant differences $(p<0.05)$. Likewise, the mean VAS in patients using MD (4.59 \pm 0.72$)$ was less than the mean VAS in patients using CD (5.43 \pm 0.75$)$; there were significant differences $(\mathrm{p}<0.05)$. The duration of the wound stated to improve in patients treated with MD was $13.67 \pm 6.09$ days, which is slightly faster than the wound care performed for the patients treated with CD after $14.00 \pm 7.64$ days. There was no significant difference ( $p>0.05)$. Similarly, referring to the direct cost for the patients treated with MD $(527.63 \pm 84.47)$, it was slightly higher than for CD $(482.68 \pm 98.08)$ but not significantly different $(\mathrm{p}>$ 0.05). The initial BWAT score for patients treated with MD was $35.07 \pm 2.12$, which is the same as the initial BWAT score for patients treated with CD, which was $35.00 \pm 1.70(p>0.05)$. The last BWAT score in patients using MD (27.60 \pm 2.06$)$ was better than the last BWAT score of the patients using CD (30.70 \pm $2.36)$; there was a significant difference $(p<0.05)$. Likewise, the mean BWAT score in patients using MD $(31.26 \pm 1.69)$ was better than the average BWAT score of patients using CD $(33.07 \pm 1.65)$; there was a significant difference $(\mathrm{p}<0.05)$.

\section{DISCUSSION}

According to the demographic data, most of the causes of injuries were traffic accidents. It was found that the majority of patients were male (76\%) and the rest were female (24\%). Among the patients who used $\mathrm{MD}, 87 \%$ of them were male and $13 \%$ were female. Regarding the patients who used CD, 60\% were male and $40 \%$ were female. These results are consistent with other studies where men are the more common accident victims compared to women with a ratio of 3.2: 1 (Laiou et al., 2016). This relates to the proportion of road users being mostly male and the characteristics and attitudes of male motorists during traffic (Nastiti, 2017).

Based on age, it was found that the majority of patients were younger than 30 years old $(40 \%)$. The patients aged $30-50$ years totaled $36 \%$ and those over 50 years totaled $24 \%$. In the patients using MD, it was found that the majority of patients were under the age of 30 years ( $40 \%)$, the patients aged $30-50$ years totaled $33 \%$ and those over 50 years old totaled $27 \%$. In the patients using $\mathrm{CD}$, it was found that the patients under 30 years old totaled $40 \%$, the patients aged 30 50 years totaled $40 \%$ and those over 50 years totaled $20 \%$. The traffic accidents predominantly involved motorcycle riders with an average age of 15-29 years

Table 2. Comparison of Modern and Classic Dressings in Terms of Patient Comfort, Cost Effectiveness and Wound Healing

\begin{tabular}{|c|c|c|c|}
\hline Parameter & MD (n=15) & CD $(n=10)$ & $\mathbf{p}$ \\
\hline Wide of wounds & $233.13 \pm 91.97$ & $170.60 \pm 117.01$ & $0.055^{\mathrm{u}}$ \\
\hline Frequent of wound care & $3.07 \pm 0.88$ & $4.60 \pm 1.84$ & $0.021^{\mathrm{u}}$ \\
\hline Initial VAS & $7.27 \pm 0.96$ & $7.40 \pm 0.84$ & $0.676^{\mathrm{u}}$ \\
\hline \multirow[t]{2}{*}{ VAS } & $2.60 \pm 0.63$ & $3.90 \pm 0.74$ & $0.001^{\mathrm{u}}$ \\
\hline & $4.59 \pm 0.72$ & $5.43 \pm 0.75$ & $0.014^{\mathrm{u}}$ \\
\hline $\begin{array}{l}\text { Length of stay before soft tissue coverage } \\
\text { procedure (Indirect cost) }\end{array}$ & $13.67 \pm 6.09$ & $14.00 \pm 7.64$ & $0.317^{\mathrm{t}}$ \\
\hline Direct cost & $527.63 \pm 84.47$ & $482.68 \pm 98.08$ & $0.267 \mathrm{u}$ \\
\hline \multirow{3}{*}{ BWAT } & $35.07 \pm 2.12$ & $35.00 \pm 1.70$ & $0.533^{\mathrm{t}}$ \\
\hline & $27.60 \pm 2.06$ & $30.70 \pm 2.36$ & $0.001^{\mathrm{u}}$ \\
\hline & $31.26 \pm 1.69$ & $33.07 \pm 1.65$ & $0.017^{u}$ \\
\hline
\end{tabular}

$\mathrm{u}=$ Mann-Whitney test

$\mathrm{t}=$ independent T-test 
old, which is within the productive age range (Nastiti, 2017). Teenagers and young adults, especially from among the male population, were most at risk of traffic accidents, with the prevalence rates ranging from 11.1 to $42.6 \%$ for the 20 -30 years old age group and from 4.6 to $97.2 \%$ for male subjects overall (Khatib, Gaidhane, Quazi, \& Khatib, 2015).

In terms of patient comfort, the indicators were assessed included frequency of wound care being done and the pain scale during the wound care procedure being performed. In this study, the frequency of wound care performed on patients using CD was more often when compared to the wound care when done using $\mathrm{CD}$. In addition, the pain scale experienced by patients treated with MD and CD was also different, where the patients who used MD tended to find it less painful than those who used CD. Wound care is an action used to achieve wound healing which involves different emotional aspects for each individual who experiences it, including pain. The more frequently that wound care is done, the more likely it is that the patient feels uncomfortable. It is undeniable that pain can affect wound care procedures. Pain that is not treated adequately can have a negative impact on wound healing and the quality of life of the patients. In a multinational study conducted by the European Wound Management Association (EWMA), clinicians assessed that the time to change the dressings when wound care is performed is where pain is felt most severely (Moffatt, Franks, \& Hollingworth, 2004). Pain during wound care (procedural pain) is closely related to the type of dressing used and this can be assessed using VAS. The selection of a type of dressing that does not adhere to the wound base and that can be easily removed will be very helpful in terms of reducing patient pain (S Calne, Day, \& Pediani, 2004; Granick, Sood, \& Tomaselli, 2014). Gauze is most likely to cause pain because it tends to be more adherent to the wound base and Siltec is a type of silicone dressing that is more easily released when changing dressings. According to Morris (2009), based on his research on burns in pediatric patients, the use of silicone dressings can minimize the incidence of trauma and pain in most patients who are the subject of his research (Morris, 2009).

In terms of cost effectiveness, especially indirect costs, it can be seen from the duration of the wound that it is good to do the soft tissue coverage procedure. This measurement can also be based on the Length of Stay / LOS. In this study, the indirect cost of using CD was the same as the wound care for patients using MD, which was in parallel to direct cost. In other words, the costs incurred in the use of both types of dressings for wound care were not much different. According to Hutchinson (1990), the use of gauze for wound care is indeed cheaper but its duration for subsequent dressing changes is too short. This risks increasing the occurrence of infection in the wound (Hutchinson \& McGuckin, 1990).
Furthermore, when viewed in terms of wound healing, the BWAT score can give us an idea of the wound condition of each patient when first treated until the end when the wounds are declared to be ready for the soft tissue coverage procedure (Greatrex-White \& Moxey, 2015; Sussman \& BatesJensen, 2007). The initial BWAT score for each wound, whether treated using CD or MD, showed no significant difference. By comparing the last BWAT score and the average BWAT score of the wounds treated using MD and $\mathrm{CD}$, different scores were obtained. The last BWAT score and the mean show better and significant healing for the wounds treated using MD (see Figures 1 and 2). CutimedSorbact was used as a primary wound dressing because its active material in the form of dialkylcarbomyl chloride (DACC) is able to bind bacteria and other microorganisms from contaminated wounds. The active material has strong hydrophobic properties that are used to bind microorganisms that have cell surface hydrophobicity (CSH) quickly and effectively. This includes gram-positive bacteria such as S.aureus, Methicillin-Resistant Staphylococcus aureus (MRSA), Streptococci, gram-negative bacteria such as E.coli, Clostridium difficileand P.aeruginosa, and types of fungi such as C.albicans (Cutting \& McGuire, 2015). As stated by Ljungh et al (2006), hydrophobic dressings should be used for wounds with exudates to bind microorganisms that express CSH (Ljungh, Yanagisawa, \& Wadstrom, 2006). In addition, Cooper and Jenkins (2016) reported the efficacy of DACC on CutimedSorbact concerning binding the biofilms formed by pathogens MRSA and P.aeruginosa (Cooper \& Jenkins, 2016). As a secondary dressing, CutimedSiltec was used in this study because of its nature as an absorbent of silicon. This is very useful for absorbing any excess exudate in the wound. This is consistent with the research conducted by Rook et al (2019) which states that silicone dressings (a type of modern dressing material) have the ability to reduce exudates, to provide a moist wound environment for optimal healing, to keep the tissue around the wound healthy, to avoid maceration, and to minimize pain (Boateng, Matthews, Stevens, \& Eccleston, 2008; Rook, Davies, Frenthoff, \& Wurfel, 2019). The use of CutimedSiltec with material from silicone foam is instrumental to deliver water vapor and oxygen, in addition to providing thermal insulation to the wound bed. Its main advantage is its ability to accommodate exudates and is able to protect healthy tissue around the wound, because the material is highly absorbent and able to spread the exudate evenly throughout the absorbent layer and prevent leakage with semi-permeable material on the back (Jones, Grey, \& Harding, 2006; Vermeulen H, Ubbink D, Goossens A, de Vos R, \& Legemate D, 2005).

\section{CONCLUSION}

In terms of patient comfort, including the frequency of wound care and the pain scale during wound care, modern dressings have advantages over classic 
dressings. Based on the comparison of the indirect and direct costs, modern dressings have the same cost effectiveness as classic dressings. In terms of wound healing using the BWAT score, modern dressings have better efficacy compared to classic dressings.

\section{REFERENCES}

Al-Gharibi, K. A., Sharstha, S., \& Al-Faras, M. A. (2018). Cost-effectiveness of wound care a concept analysis. Sultan Qaboos University Medical Journal, 18(4), e433-e439. https://doi.org/10.18295/squmj.2018.18.04.002

Bates-Jensen, B. M., McCreath, H. E., Harputlu, D., \& Patlan, A. (2019). Reliability of the Bates-Jensen wound assessment tool for pressure injury assessment: The pressure ulcer detection study. Wound Repair and Regeneration, 27(4), 386-395. https://doi.org/10.1111/wrr.12714

Bechert, K., \& Abraham, S. E. (2009). Pain Management and Wound Care. Journal of the American College of Certified Wound Specialists, 1(2), 65-71. https://doi.org/10.1016/j.jcws.2008.12.001

Boateng, J., Matthews, K., Stevens, H., \& Eccleston, G. (2008). Wound Healing Dressings and Drug Delivery Systems : A Review. Indian J Pharml Sci, 97(8), 2892-2923. https://doi.org/10.1002/jps

Calne, S, Day, K., \& Pediani, R. (2004). Minimising pain at wound dressing-related procedures: A consensus document. In Suzie Calne, K. Day, \& R. Pediani (Eds.), A World Union of Wound Healing Societies. Paris: Medical Education Partnership Ltd.

Cooper, R., \& Jenkins, L. (2016). Binding of two bacterial biofilms to dialkyl carbamoyl chloride (DACC)-coated dressings in vitro. Journal of Wound Care, 25(2), 76-82. https://doi.org/10.12968/jowc.2016.25.2.76

Cutting, K., \& McGuire, J. (2015). In vitro and clinical experience of Cutimed Sorbact: the evidence base. Journal of Wound Care, 24(5), S6-S30. https://doi.org/10.12968/jowc.2015.24.Sup5a.S 6

Daunton, C., Kothari, S., Smith, L., \& Steele, D. (2012). A history of materials and practices for wound management. Wound Practice and Research, 20(4), 174-186. Retrieved from https://search.informit.com.au/documentSumma ry;dn=058025628512911;res=IELHEA

Delgado, D. A., Lambert, B. S., Boutris, N., McCulloch, P. C., Robbins, A. B., Moreno, M. R., \& Harris, J. D. (2018). Validation of Digital Visual Analog Scale Pain Scoring With a Traditional Paper-based Visual Analog Scale in Adults. JAAOS: Global Research and Reviews, 2(3), e088. https://doi.org/10.5435/jaaosglobal-d-17-00088

Gonzalez, A. C. D. O., Andrade, Z. D. A., Costa, T. F., \& Medrado, A. R. A. P. (2016). Wound healing - A literature review. Anais Brasileiros de Dermatologia, 91(5), 614-620. https://doi.org/10.1590/abd1806-
4841.20164741

Granick, M. S., Sood, A., \& Tomaselli, N. L. (2014). Wound Dressings and Comparative Effectiveness Data. Wound Healing Society, 3(8), 511-529. https://doi.org/10.1089/wound.2012.0401

Greatrex-White, S., \& Moxey, H. (2015). Wound assessment tools and nurses' needs: An evaluation study. International Wound Journal, 12(3), 293301. https://doi.org/10.1111/iwj.12100

Gurtner, G. (2007). Wound healing: normal and abnormal. In C. Thorne, R. Beasley, S. Aston, S. Barlett, G. Gurtner, \& S. Spear (Eds.), Grabb and Smith's plastic surgery (6th Ed, pp. 15-22). Philadelphia: Lippincott Williams \& Wilkins.

Hurley, H., Knepper, B., \& Price, C. (2013). Avoidable antibiotic exposure for uncomplicated skin and soft tissue infections in the ambulatory care setting. Am J Med 126, 12(126), 1099-1106. https://doi.org/10.1016/j.amjmed.2013.08.016.

Hutchinson, J., \& McGuckin, M. (1990). Occlusive dressings: a microbiologic and clinical review. $A m$ J Infect Cont, 18(4), 257-268. https://doi.org/10.1016/0196-6553(90)90167Q

Jones, V., Grey, J. E., \& Harding, K. G. (2006). ABC of wound healing. Wound dressings. BMJ, 332(April), 777-780. https://doi.org/10.1136/bmj.332.7544.777

Khatib, M., Gaidhane, A., Quazi, Z., \& Khatib, N. (2015). Prevalence pattern of road traffic accidents in developing countries - a systematic review. IJMSPH, 4(10), 1324-1333. https://doi.org/10.5455/ijmsph.2015.09012015 334

Laiou, A., Folla, K., Yannis, G., Bauer, R., Machata, K., Brandstaetter, C., et al. (2016). Comparative analysis of road accidents by gender in Europe. BMJ, 22, 4-6. https://doi.org/10.1136/injuryprev-2016042156.856

Ljungh, A., Yanagisawa, N., \& Wadstrom, T. (2006). Using the principle of hydrophobic interaction to bind and remove wound bacteria. Journal of Wound Care, 15(4), 175-180. https://doi.org/12968/jowc.2006.15.4.26901

Moffatt, C., Franks, P., \& Hollingworth, H. (2004). Pain at wound dressing changes. In EWMA Position Document. London: Medical Education Partnership Ltd.

Morris, C. (2009). Use of wound dressings with soft silicone adhesive technology. Paediatric Nursing, 21(3), 38-43. https://doi.org/10.7748/paed2009.04.21.3.38.c7 037

Morrison, M., Moffatt, C., \& Franks, P. (2007). Leg Ulcers: A Problem-Based Learning Approach. Philadelphia: Mosby, Elsevier.

Nastiti, F. (2017). Hubungan antara kepemilikan SIM C dan keikutsertaan dalam tes pembuatan SIM dengan pengetahuan berkendara dan kecelakaan lalu lintas di Kabupaten Sidoarjo. Fakultas Kesehatan Masyarakat, Universitas Airlangga, 


\section{F. MAHYUDIN ET AL.}

167-178.

https://doi.org/10.20473/ijph.v12i1.2017.167178

Rook, S., Davies, P., Frenthoff, E., \& Wurfel, T. (2019). Mepilex® Border Flex - results of an observational study in German specialist wound care centres. Wounds International, 10(1).

Sussman, C., \& Bates-Jensen, B. (2007). Tools to measure wound healing. In Wound Care: A Collaborative Practice Manual (p. 159). Philadelphia: Wolters Kluwer Health.

Thatte, M. R., Babhulkar, S., \& Hiremath, A. (2013). Brachial plexus injury in adults: Diagnosis and surgical treatment strategies. Annals of Indian
Academy of Neurology, 16(1), 26-33. https://doi.org/10.4103/0972-2327.107686

Vermeulen H, Ubbink D, Goossens A, de Vos R, \& Legemate D. (2005). Dressings and topical agents for surgical wounds healing by secondary intention ( Review ) Dressings and topical agents for surgical wounds healing by secondary intention. Cochrane Database Syst Rev, 4(1), 1012.

https://doi.org/10.1002/14651858.CD003554.p ub2.Copyright 